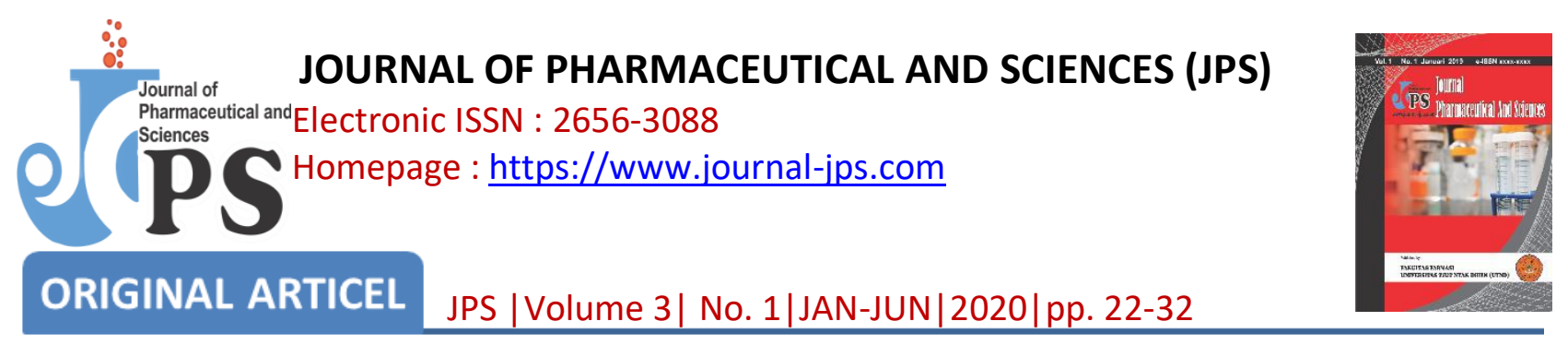

\title{
Physicochemical Study of Mangosteen (Garcinia mangostana L.) peel Extract as Coloring Agent in Tablet Formulation
}

\section{Studi Fisikokimia Ekstrak Kulit Buah Manggis (Garcinia mangostana L.) Sebagai Pewarna Pada Formulasi Tablet}

\author{
Ridho Asra1), Rusdi 1), Riri Nofrianti 1) \\ Sekolah Tinggi IImu Farmasi (STIFARM) Padang \\ e-mail author: ridhoasra@gmail.com
}

\begin{abstract}
The mangosteen peel (Garcinia mangostana L.) contains anthocyanin pigments, which has an important role in coloring. This study aims to determine the physicochemical properties of mangosteen peel extract (Garcinia mangostana L.) with two methods, which is an examination with UV-Vis and FTIR spectrophotometry. Then the extract was characterized, identified, and analyzed for its stability against temperature, $\mathrm{pH}$, and applied as a coloring agent in the formulation of pharmaceutical preparations (tablets). The results showed that the yield of mangosteen peel extract obtained $13.0975 \%$, drying losses $5.2822 \%$, total ash content $14.488 \%$, acid insoluble ash content $0.684 \%$, water-soluble extract content $29.58 \%$, extract content dissolved in ethanol $37.78 \%$, total anthocyanin content with $\lambda$ max $=367 \mathrm{~nm}$ which is $=9.58$ $\mathrm{mg} / 100 \mathrm{~g}$ and with $\lambda \max =289 \mathrm{~nm}$ which is $=52.43 \mathrm{mg} / 100 \mathrm{~g}$. In this study, the anthocyanin pigment content in mangosteen peel extract cannot be used as an alternative to natural dyes for pharmaceutical preparations (tablets).
\end{abstract}

Keywords : Mangosteen peel; anthocyanin extract; physicochemical properties; tablets.

\section{ABSTRAK}

Kulit buah manggis (Garcinia mangostana L.) mengandung pigmen antosianin yang berperan penting dalam pewarnaan. Tujuan penelitian adalah untuk mengetahui sifat fisikokimia ekstrak kulit buah manggis (Garcinia mangostana L.) dengan melakukan ekstraksi, dikarakterisasi menggunakan spektrofotometri UVVis dan FTIR, diidentifikasi, dan dianalisis stabilitasnya terhadap suhu dan $\mathrm{pH}$, serta digunakan untuk coloring agent pada formulasi tablet. Rendemen ekstrak kulit buah manggis didapatkan $13,0975 \%$, susut pengeringan 5,2822 \%, kadar abu total $14,498 \%$, kadar abu tidak larut asam 0,684 \%, kadar sari yang larut dalam air 29,58 \%, kadar sari yang larut dalam etanol $37,78 \%$, kadar total antosianin dengan $\lambda_{\max }=367 \mathrm{~nm}$ yaitu $=9,58 \mathrm{mg} / 100 \mathrm{~g}$ dan dengan $\lambda \mathrm{max}=289 \mathrm{~nm}$ yaitu $=52,43 \mathrm{mg} / 100 \mathrm{~g}$. Pada penelitian ini kandungan pigmen antosianin di dalam ekstrak kulit buah manggis, tidak dapat digunakan sebagai pewarna alami dalam formulasi tablet.

Kata kunci: Kulit Buah Manggis (Garcinia mangostana L.); antosianin; ekstrak; sifat fisikokimia; tablet. 


\section{PENDAHULUAN}

Pewarna adalah zat penting yang mampu meningkatkan daya tarik konsumen terhadap suatu produk. Namun, beberapa produsen menggunakan pewarna sintetik dan pewarna tekstil yang berdampak buruk bagi kesehatan, salah satunya adalah dapat menyebabkan kanker (Lestario et al., 2004). Dalam formulasi sediaan farmasi, zat warna makanan banyak digunakan. Tujuan penambahan zat warna adalah untuk membedakan antara obat-obatan yang dikonsumsi serta mengurangi kesalahan dalam penggunaan obat (Sulekova et al., 2017).

Buah manggis (Garcinia mangostana L.) mengandung zat warna alami (Prihatman, 2000). Kulit buah manggis mengandung pigmen antosianin yang berperan penting dalam pewarnaan (Hidayat \& Saati, 2006). Antosianin merupakan salah satu zat pewarna alami karena merupakan zat berwarna merah, jingga, ungu, atau biru yang banyak tersedia pada bunga dan buah-buahan. Penggunaan bahan pewarna alami ini masih terbatas pada beberapa produk makanan dan minuman. Antosianin dapat diekstraksi dari tumbuhan menggunakan pelarut asam asetat atau asam hidroklorida (Harborne, 1987).

Proses ekstraksi umumnya dilakukan dengan menggunakan metode konvensional (maserasi, sokletasi, dan refluks). Namun, teknik tersebut membutuhkan banyak waktu dan kurang efisien. Berdasarkan hal tersebut, dibutuhkan teknik ekstraksi alternatif diantaranya ekstraksi metode ultasonik (Ramli et al., 2014). Metode Ultrasound Assisted Extraction (UAE) merupakan teknik ekstraksi dengan memberikan gelombang ultrasonik pada bahan yang akan dilakukan ekstraksi (Chemat et al., 2011).

Sediaan tablet merupakan jenis sediaan yang paling banyak diproduksi dan juga banyak mengalami perkembangan dalam formulasinya. Beberapa keuntungan sediaan tablet adalah sediaan lebih kompak, dosisnya tepat, mudah pengemasannya dan penggunaannya lebih praktis dibanding sediaan yang lain (Banker \& Anderson, 1994).

Penelitian ini bertujuan untuk mengetahui sifat fisikokimia ekstrak kulit buah manggis (Garcinia mangostana L.) dengan dua metode yaitu pemeriksaan dengan spektrofotometri UVVis dan Spektrofotometri Infra Merah. Kemudian zat warna merah ekstrak dikarakterisasi, diidentifikasi, dan dianalisa stabilitasnya terhadap suhu dan $\mathrm{pH}$, kemudian digunakan sebagai pewarna dalam formulasi sediaan tablet. Hasil penelitian dapat menjadi alternatif zat warna sintetik dan pemanfaatan zat warna alami dari limbah kulit manggis dapat mengurangi pencemaran lingkungan dari pewarna sintetik.

\section{METODE PENELITIAN}

\section{Waktu dan Tempat Penelitian}

Penelitian ini telah dilaksanakan dari bulan Januari sampai Mei 2019 di Herbarium Universitas Andalas Jurusan Biologi FMIPA, di Laboratorium Kimia Sekolah Tinggi IImu Farmasi (STIFARM) Padang dan Laboratorium FMIPA Universitas Negeri Padang.

\section{Alat}

Alat-alat yang digunakan antara lain: Spektrofotometer UV-Vis (UV-1700 PharmaSpec), Fourier Transform Infrared (FTIR) (PerkinElmer), sonicator water bath (Elmasonic), Freeze Dryer (Alpha 1-2 Ldplus), timbangan analitik (KernABC), blender, corong (Iwaki), plat KLT silika gel $60 \mathrm{~F}_{254}$ (Merck), alat-alat gelas laboratorium (Iwaki), lampu sinar UV (Camag).

\section{Bahan}

Bahan yang digunakan adalah kulit buah manggis (Garcinia mangostana L.), asam asetat (PT Brataco), air suling (PT Brataco), etanol 70\% (PT Brataco), metanol (PT Brataco), natrium hidroksida (PT Brataco), asam klorida (PT Brataco).

\section{PROSEDUR PENELITIAN}

\section{Pengambilan Sampel}

Sampel yang digunakan pada penelitian ini adalah kulit buah manggis (Garcinia mangostana L.) segar sebanyak tiga $\mathrm{kg}$ yang diperoleh dari perkebunan warga di Lubuk Minturun, Kecamatan Koto Tangah, Sumatera Barat.

\section{Determinasi Sampel}

Determinasi dilakukan di Herbarium Universitas Andalas (ANDA) Jurusan Biologi Fakultas Matematika dan Ilmu Pengetahuan Alam, Universitas Andalas Padang. 


\section{Penyiapan Sampel}

Sampel buah manggis dicuci dan dikupas untuk memisahkan buah dengan kulitnya. Kemudian, kulit buah dirajang dan diblender hingga halus (Sholihah et al., 2017)

\section{Metode Ekstraksi dengan Ultrasonic-Assisted Extraction (UAE)}

Sebanyak 400 gram serbuk kulit buah manggis dicampurkan dengan air $800 \mathrm{~mL}$ selama beberapa menit dengan perbandingan 1:2 (b:v). Maserat kemudian disonikasi selama 30 menit pada $50 \mathrm{kHz}\left(25{ }^{\circ} \mathrm{C}\right)$. Kemudian disaring menggunakan kertas saring Whatman no. 1 sehingga diperoleh larutan berwarna. Residu diekstraksi kembali dengan air untuk mendapatkan zat warna merah secara sempurna. Campuran maserat kemudian disentrifugasi pada 6000 rpm selama 15 menit pada suhu kamar dan supernatan disimpan. Ekstraksi kulit buah manggis dilakukan sebanyak 3 kali pengulangan (Sholihah et al., 2017). Kemudian, supernatan selanjutnya di keringkan dengan alat freeze drying.

\section{Rendemen Ekstrak}

Rendemen dihitung dengan cara membandingkan bobot ekstrak sebelum di freeze drying dengan bobot ekstrak kering yang telah di freeze drying.

\section{Uji Kromatografi Lapis Tipis (KLT)}

Ekstrak dipisahkan menggunakan KLT dengan eluen n-Butanol:asam asetat:air (4:1:5) dan asam klorida $(\mathrm{HCl}) 1 \%$, dimana eluen yang memberikan paling baik saat pemisahan akan digunakan dalam pemisahan KLT Preparatif. Pada pemisahan dengan KLT Preparatif digunakan plat silika $\mathrm{G} 60 \mathrm{~F}_{254}$ dengan ukuran 10 X $10 \mathrm{~cm}$. Masing-masing 1 gram ekstrak dilarutkan dengan etanol $80 \%$ dan $\mathrm{HCL} 1 \%$ sebanyak $10 \mathrm{~mL}$, kemudian ditotolkan sepanjang plat pada jarak $2 \mathrm{~cm}$ dari garis bawah dan $1 \mathrm{~cm}$ dari garis atas. Selanjutnya dielusi dengan menggunakan eluen n-Butanol:asam asetat:air (4:1:5). Nilai Retention factor ( $R f)$ dari noda dihitung dan diperiksa dibawah sinar UV pada panjang gelombang $254 \mathrm{~nm}$ dan $366 \mathrm{~nm}$ dan dibandingkan dengan nilai $R f$ antosianin pada buku referensi antosianin pustaka (Harborne, 1987).
Isolat-isolat KLT Preparatif diperoleh dengan cara mengerok fasa diam di tempat noda sampel pada plat, lalu dilarutkan dengan metanol sebanyak $5 \mathrm{~mL}$ dan disentrifugasi untuk mengendapkan fase diamnya (silika gel), lalu supernatannya diambil dan dimasukkan dalam kuvet kemudian dianalisis dengan spektrofotometer UV-Vis dan FTIR (Markham, 1987).

\section{Penentuan Panjang Gelombang Maksimum Ekstrak}

Supernatan yang telah di ambil kemudian di masukan ke dalam kuvet lalu diukur panjang gelombang maksimumnya dengan menggunakan spektrofotometer UV-Vis pada rentang panjang gelombang 200-600 nm (Syukri et al., 2013).

\section{Analisis Gugus Fungsi menggunakan FTIR}

Supernatan yang telah diambil dari hasil isolat-isolat KLT Preparatif dianalisis dengan spektroskopi Fourier Transform Infrared (FTIR) untuk mengidentifikasi gugus fungsional senyawa antosianin dalam ekstrak kulit buah manggis.

\section{Penetapan Kadar Total Antosianin dalam Sampel}

Kadar total antosianin di ukur berdasarkan absorban dari panjang gelombang maksimum ekstrak (Widyasanti et al., 2018).

$$
\text { Total antosianin }(\mathrm{ppm})=\frac{\mathrm{A} \times \mathrm{BM} \times \mathrm{FP} \times 1000}{\varepsilon \times b}
$$

Dimana :

$A=$ absorbansi

$\varepsilon=$ absorptivitas molar $(26900 \mathrm{~L} /(\mathrm{mol} . \mathrm{cm}))$

$\mathrm{b}=$ tebal kuvet $(1 \mathrm{~cm})$

$\mathrm{BM}=$ berat molekul $(449,2 \mathrm{~g} / \mathrm{mol})$

$\mathrm{FP}=$ faktor pengenceran

\section{Uji Stabilitas Ekstrak Kulit Buah Manggis Terhadap Suhu}

Timbang ekstrak kulit buah manggis sebanyak $100 \mathrm{mg}$ larutkan dengan aquadest dalam labu ukur $100 \mathrm{~mL}$. Ukur absorban sampel pada panjang gelombang 200-600 nm catat sebagai absorban kontrol (suhu ruang). Larutan ekstrak kulit buah manggis dipanaskan pada variasi temperatur $30^{\circ} \mathrm{C}, 50^{\circ} \mathrm{C}, 70^{\circ} \mathrm{C}, 90^{\circ} \mathrm{C}$ dan $100{ }^{\circ} \mathrm{C}$ dalam waktu 30 menit kemudian ukur kembali absorban sampel terhadap variasi suhu.(Alvionita et al., 2016). 


\section{Uji Stabilitas Ekstrak Kulit Buah Manggis} Terhadap $\mathrm{pH}$

Timbang ekstrak kulit buah manggis sebanyak $100 \mathrm{mg}$ larutkan dengan aquadest dalam labu ukur $100 \mathrm{~mL}$. Ukur absorban sampel pada panjang gelombang $200-600 \mathrm{~nm}$ catat sebagai absorban kontrol (tanpa variasi $\mathrm{pH}$ ). Larutan ekstrak kulit buah manggis pada variasi $\mathrm{pH} 1,3,5,7,9$, dan 11 dilakukan dengan cara menambahkan larutan $\mathrm{NaOH}$ atau $\mathrm{HCl}$ selanjutnya didiamkan selama 30 menit kemudian ukur kembali absorban sampel terhadap variasi $\mathrm{pH}$ (Alvionita et al., 2016).

\section{Aplikasi Pewarna Alami Pada Sediaan Farmasi (Tablet) \\ Ekstrak kulit buah manggis diaplikasikan dalam pembuatan tablet parasetamol dengan}

formula sebagaimana pada tabel 1 pembuatan tablet parasetamol.

Pembuatan tablet dilakukan dengan metode kempa langsung. Setiap bahan ditimbang untuk pembuatan 10 tablet dengan dosis parasetamol $500 \mathrm{mg}$ per tablet. Parasetamol dan amilum dicampur hingga homogen, kemudian dimasukkan Avicel ${ }^{\circledR} \mathrm{PH} 102$ dan pencampuran dilanjutkan kembali. Tambahkan talk dan dicampur hingga homogen, terakhir ditambahkan serbuk ekstrak kulit buah manggis. Campuran siap dicetak dengan mesin pencetak tablet. Tablet yang dihasilkan dievaluasi secara visual terhadap warna tablet dilakukan selama 13 hari.

Tabel 1. Pembuatan tablet parasetamol

\begin{tabular}{clll}
\hline No. & \multicolumn{1}{c}{ Bahan } & \multicolumn{1}{c}{ Jumlah } & \multicolumn{1}{c}{ Fungsi } \\
\hline $\mathbf{1}$ & Parasetamol & $500 \mathrm{mg}$ & Zat Aktif \\
\hline $\mathbf{2}$ & Amilum & $10 \%$ & Penghancur \\
\hline $\mathbf{3}$ & Talk & $5 \%$ & Pelicin \\
\hline $\mathbf{4}$ & Ekstrak kulit manggis & qs & Pewarna \\
\hline $\mathbf{5}$ & Avicel${ }^{\circledR P H} 102$ & ad $650 \mathrm{mg}$ & Pengisi dan pengikat \\
\hline
\end{tabular}

\section{HASIL DAN DISKUSI}

Dari penelitian yang telah dilakukan tentang studi fisikokimia senyawa antosianin dalam ekstrak kulit buah manggis (Garcinia mangostana L.) sebagai pewarna pada sediaan farmasi (tablet) diperoleh hasil sebagai berikut : Hasil identifikasi menunjukan bahwa sampel yang digunakan adalah kulit buah manggis (Garcinia mangostana L.). Hasil penentuan rendemen ekstrak kulit buah manggis didapatkan $13,0975 \%$.

Hasil uji KLT ekstrak kulit buah manggis dengan eluen n-Butanol:asam asetat:air (4:1:5) didapatkan nilai $\operatorname{Rf} 1=0,85$ dan nilai $\operatorname{Rf} 2=0,42$. Hasil uji KLT ekstrak kulit buah manggis dengan eluen asam klorida (HCL) 1\% didapatkan nilai Rf $=0,92$. Hasil uji KLT Preparatif ekstrak kulit buah manggis dengan eluen $n$-Butanol:asam asetat:air
(4:1:5) didapatkan nilai $\operatorname{Rf} 1=0,71$ dan nilai $\operatorname{Rf} 2=$ 0,42 .

Hasil uji spektrofotometri UV-Vis ekstrak kulit buah manggis pada noda 1 memiliki nilai $\lambda \max =$ $367 \mathrm{~nm}$ dengan nilai absorban $=0,188$ dan $\lambda$ max $=296 \mathrm{~nm}$ dengan nilai absorban $=0,551$ (gambar 1) sedangkan pada noda 2 memiliki nilai $\lambda \max =$ $367 \mathrm{~nm}$ dengan nilai absorban $=0,287$ dan $\lambda$ max $=289 \mathrm{~nm}$ dengan nilai absorban $=1,570$ (gambar 2).

Hasil uji spektrum inframerah ekstrak kulit buah manggis pada noda 1 terlihat adanya gugus fungsi $\mathrm{O}-\mathrm{H}$ pada bilangan gelombang 3322,44 $\mathrm{cm}-1$ gugus fungsi $-\mathrm{CH} 3,-\mathrm{CH} 2,-\mathrm{CH}$ aldehid pada bilangan gelombang $2941,71 \mathrm{~cm}-1$ dan 2822,40 $\mathrm{cm}-1$, gugus fungsi $\mathrm{C}-\mathrm{H}$ bending pada bilangan gelombang $1427,79 \mathrm{~cm}-1$, dan gugus fungsi $\mathrm{C}=\mathrm{C}$ $\mathrm{H}, \mathrm{Ar}-\mathrm{H}$ bending pada bilangan gelombang 674,51 
$\mathrm{cm}-1$ (gambar 3) dan hasil spektrum inframerah ekstrak kulit buah manggis pada noda 2, terlihat adanya gugus fungsi $\mathrm{O}-\mathrm{H}$ pada bilangan gelombang 3329,34 cm-1 gugus fungsi $-\mathrm{CH} 3$, $\mathrm{CH} 2$, - $\mathrm{CH}$ aldehid pada bilangan gelombang 2949,22 cm-1 dan 2836,12 cm-1, gugus fungsi $\mathrm{C} \equiv \mathrm{C}$ dan $\mathrm{C} \equiv \mathrm{N}$ pada bilangan gelombang 2179,56 $\mathrm{cm}-1$, gugus fungsi $\mathrm{C}=\mathrm{O}$ (asam, aldehid, keton, amida, ester, anhidrida), $\mathrm{C}=\mathrm{C}$ (aromatic dan alfatik), dan $\mathrm{C}=\mathrm{N}$ pada bilangan gelombang $1692,24 \mathrm{~cm}-1$, gugus fungsi $\mathrm{C}-\mathrm{H}$ bending pada bilangan gelombang 1414,96 cm-1, dan gugus fungsi $\mathrm{C}=\mathrm{C}-\mathrm{H}$, Ar-H bending pada bilangan gelombang $721,72 \mathrm{~cm}-1$ (gambar 4). Hasil penentuan kadar total antosianin $\lambda \max =367 \mathrm{~nm}$ yaitu $=9,58 \mathrm{mg} / 100 \mathrm{~g}$ dan $\lambda \max =289 \mathrm{~nm}$ yaitu $=$ $52,43 \mathrm{mg} / 100 \mathrm{~g}$.

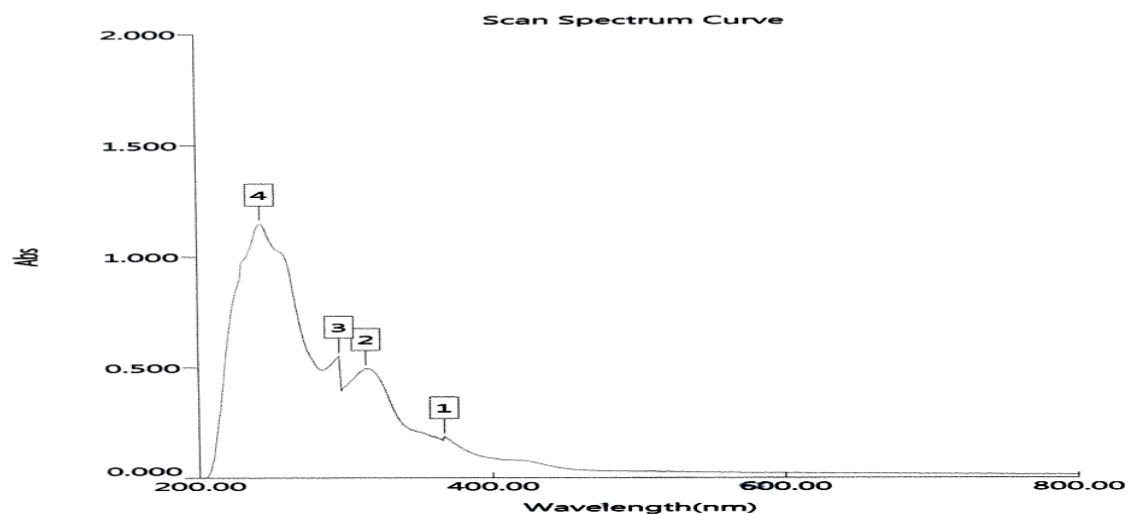

Gambar 1. Hasil spektrofotometri UVNIS ekstrak kulit buah manggis pada noda 1

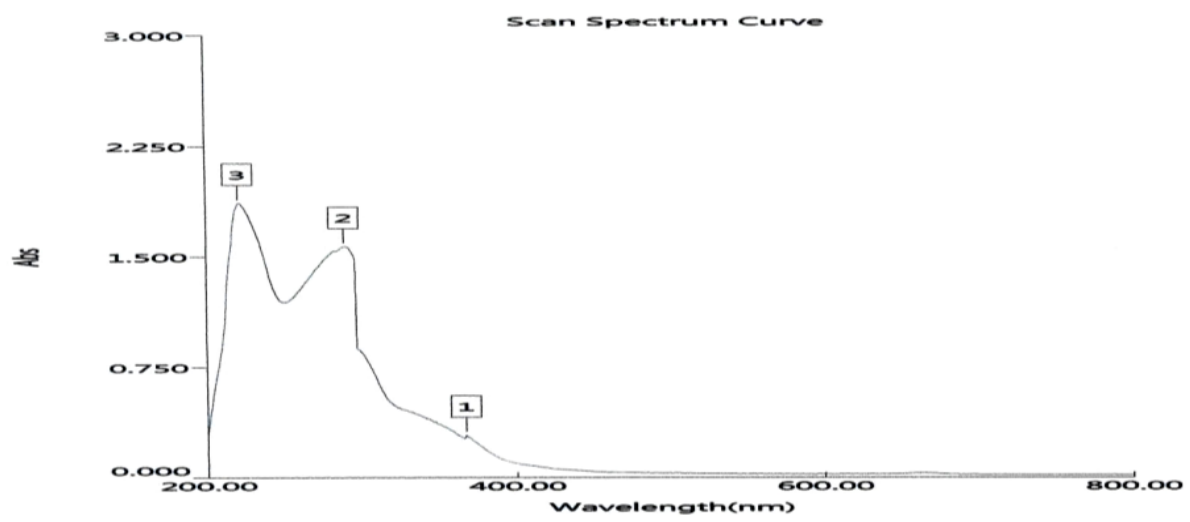

Gambar 2. Hasil spektrofotometri UVIVIS ekstrak kulit buah manggis pada noda 2 


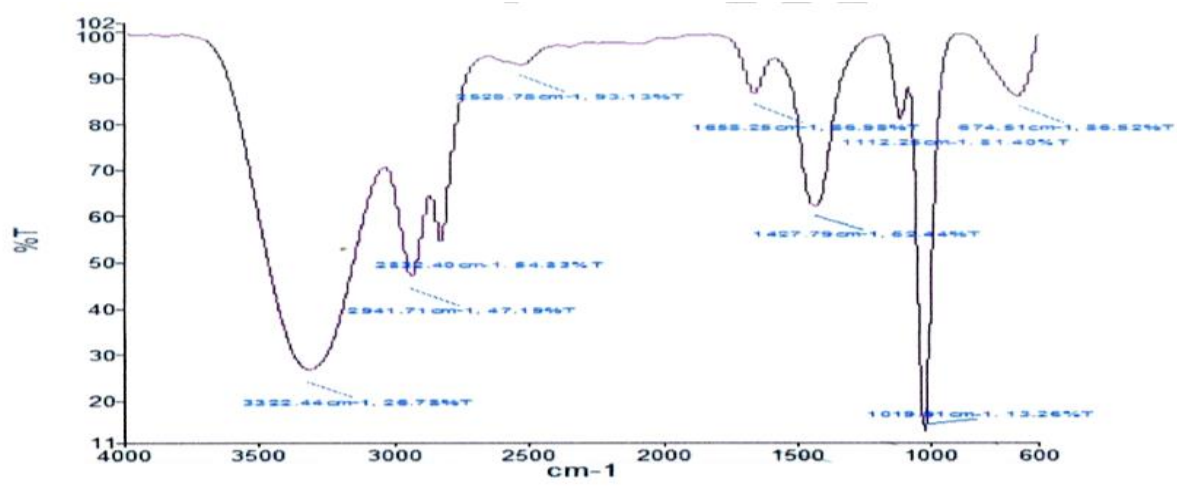

Gambar 3. Hasil spektrum inframerah kulit manggis pada noda 1.

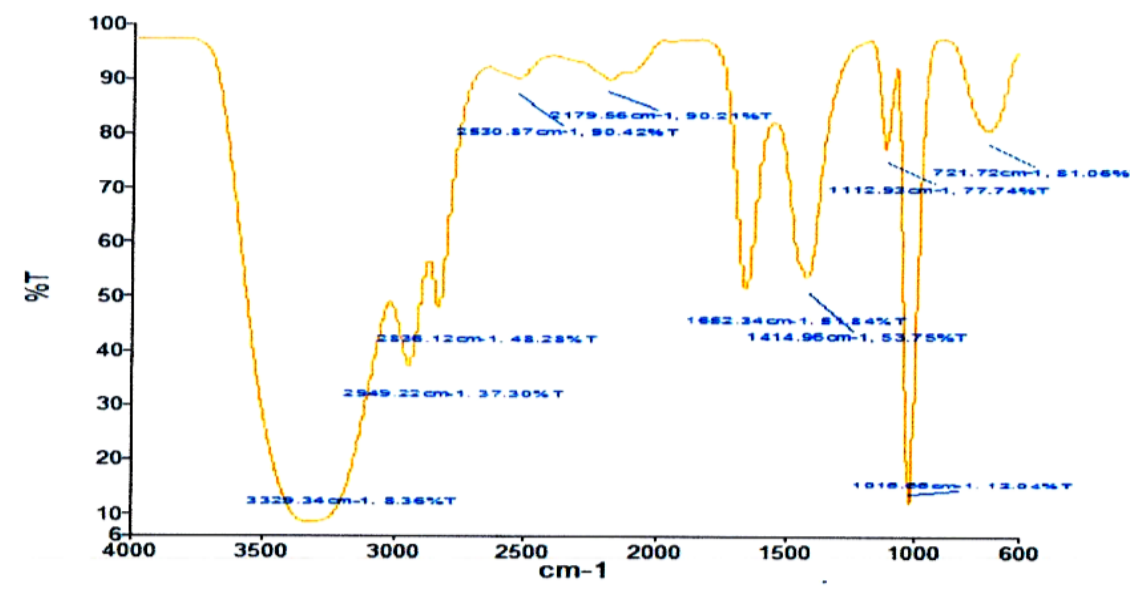

Gambar 4. Hasil spektrum inframerah kulit manggis pada noda 2



Gambar 5. Grafik hasil uji stabilitas ekstrak kulit buah manggis terhadap variasi suhu dengan panjang gelombang $289 \mathrm{~nm}$ dan $367 \mathrm{~nm}$. 


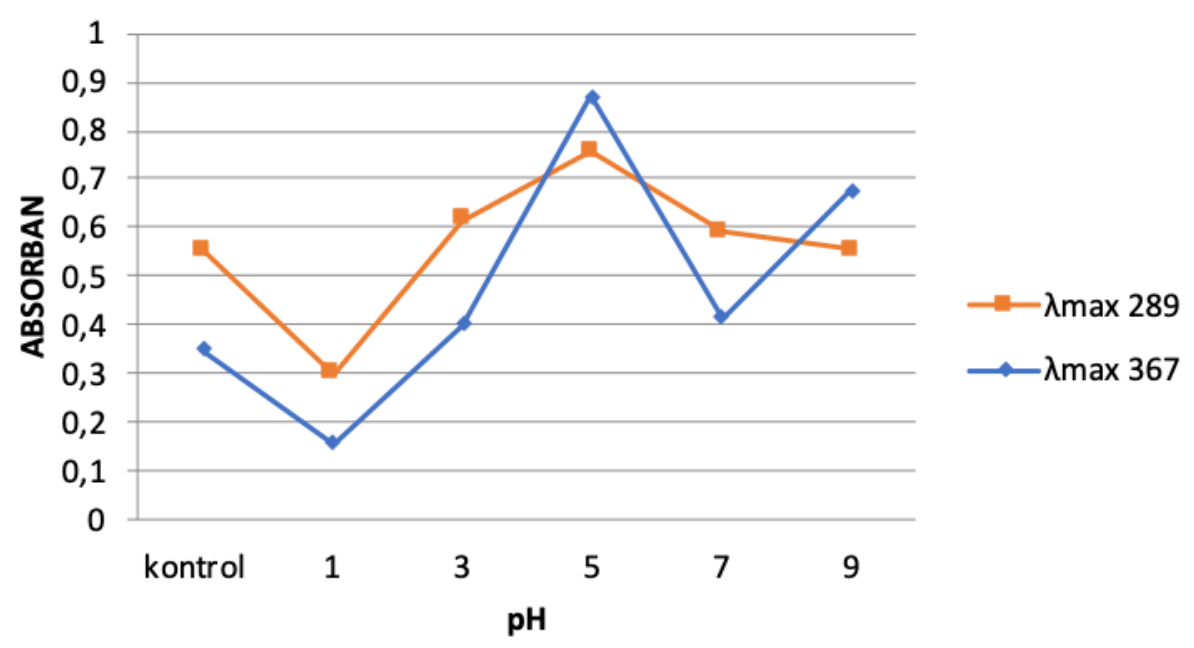

Gambar 6. Grafik Hasil uji Stabilitas Ekstrak Kulit Buah Manggis Terhadap Variasi pH dengan panjang gelombang $289 \mathrm{~nm}$ dan $367 \mathrm{~nm}$
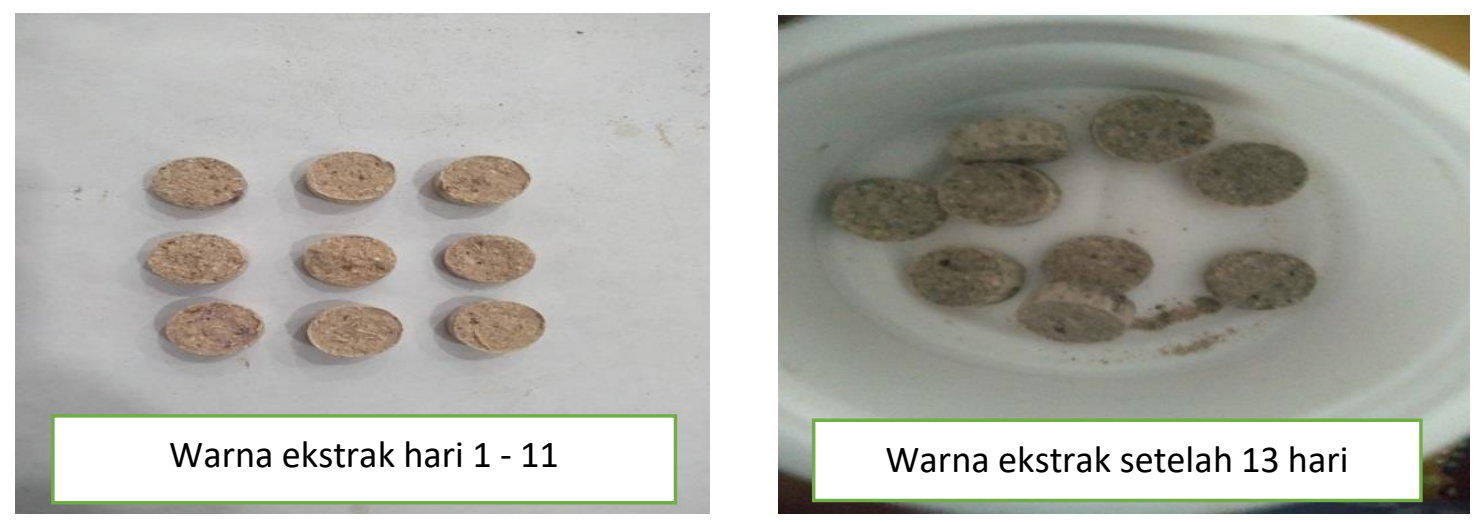

Gambar 7. Apilkasi warna ekstrak kulit buah manggis pada sediaan farmasi (tablet)

Kemudian, kulit buah dirajang dan diblender hingga halus. Sebanyak 400 gram kulit buah manggis dihomogenkan dengan air suling 800 $\mathrm{mL}$ selama beberapa menit dengan perbandingan $1: 2$ (b:v). Maserat kemudian ditempatkan dalam ultrasonic bath dan disonikasi pada $50 \mathrm{kHz}$ selama 30 menit pada suhu kamar $\left(25^{\circ} \mathrm{C}\right)$. Ampasnya dipisahkan dengan corong melalui kertas saring Whatman Nomor 1 sehingga diperoleh larutan berwarna.

Residu diekstraksi kembali dengan air untuk mendapatkan zat warna secara sempurna. Kemudian, campuran maserasi tersebut disentrifugasi pada 6000 rpm selama 15 menit pada suhu kamar dan supernatan disimpan. Ekstraksi kulit buah manggis dilakukan sebanyak 3 kali pengulangan. Kemudian, supernatan selanjutnya di keringkan dengan alat freeze drying.
Ekstrak kulit buah manggis yang didapat dari penelitian ini adalah ekstrak kering yang dihasilkan dari metode freeze drying dengan menggunakan metode tersebut mutu hasil pengeringan, khususnya untuk produk-produk yang sensitif terhadap panas menjadi lebih unggul dibandingkan metoda lainnya, antara lain adalah dapat mempertahankan stabilitas produk (menghindari perubahan aroma, warna, dan unsur organoleptik lain) dan dapat mempertahankan stabilitas struktur bahan (pengkerutan dan perubahan bentuk setelah pengeringan sangat kecil) (Liapis et al., 1995).

Hasil ekstrak kulit buah manggis kering yang didapatkan dari $400 \mathrm{~g}$ sampel kulit buah manggis adalah $53,9821 \mathrm{~g}$. Selanjutnya rendemen dihitung dengan cara membandingkan bobot ekstrak sebelum di freeze drying dengan bobot ekstrak kulit buah manggis kering yang telah di freeze 
drying. Hasil rendemen yang diperoleh dari ekstrak kulit buah manggis adalah 13,0975\% (Lampiran 1, Tabel III). Besar kecilnya rendemen yang diperoleh dipengaruhi oleh mutu senyawa yang terkandung didalam sampel.

Pada pemeriksaan profil Kromatografi Lapis Tipis (KLT) dilakukan dengan menggunakan uji KLT dan KLT Preparatif, sedangkan pada pemeriksaan profil fisikokimia dilakukan dengan menggunakan uji spektrofotometri UV-Vis dan FTIR. Uji KLT bertujuan untuk memisahkan senyawa pada noda-noda yang didapat. Sebelum dilakukan uji KLT Preparatif terlebih dahulu dilakukan pencarian eluen terbaik digunakan dua jenis eluen yaitu n-Butanol:Asam asetat:Air (4:1:5) dan $\mathrm{HCl} 1 \%$ (Harborne, 1987).

Hasil uji KLT ekstrak kulit buah manggis dengan eluen n-Butanol:asam asetat:air (4:1:5) didapatkan nilai $\operatorname{Rf} 1=0,85$ dan nilai $\operatorname{Rf} 2=0,42$. Hasil uji KLT ekstrak kulit buah manggis dengan eluen asam klorida $(\mathrm{HCl}) 1 \%$ didapatkan nilai $\mathrm{Rf}=$ 0,92 . Berdasarkan hasil KLT ekstrak kulit buah manggis dengan eluen $\mathrm{n}$-Butanol:Asam asetat:Air dan $\mathrm{HCl} 1 \%$, maka eluen yang bisa digunakan untuk uji KLT Preparatif atau dikatakan eluen terbaik adalah n-Butanol:Asam asetat:Air (4:1:5). Dimana pada pemisahan pelarut dengan pelarut n-Butanol:Asam asetat:Air senyawa pada noda dapat terpisah dengan baik yang mana ini sesuai dengan niai $R f$ antosianin dalam fase gerak BAA adalah sedang (0,1-0,4) (Harborne, 1987) .

Setelah didapatkan eluen terbaik, dilanjutkan dengan uji KLT Preparatif (KLTP) dengan menggunakan fase diam plat KLT G60 F254 yaitu untuk memisahkan senyawa berdasarkan pita-pita yang terlihat dibawah sinar UV $366 \mathrm{~nm}$. Hasilnya diketahui bahwa terdapat 2 noda pada ekstrak kulit buah manggis (Lampiran 1, Gambar 6) dengan nilai $\operatorname{Rf} 1=0,71$ dan nilai $\operatorname{Rf} 2=0,42$. Selanjutnya dari kedua noda yang dihasilkan dari KLTP, dikerok dan diekstraksi dengan metanol, kemudian disentrifus, supernatannya diambil untuk analisis spektrofotometer UV-Vis dan FTIR. Uji spektrofotometer UV-Vis bertujuan untuk melihat spektrum $\lambda_{\max }$ dan nilai absorban dari tiap noda yang didapat.

Senyawa antosianin memiliki dua penyerapan karakteristik pada daerah panjang gelombang yaitu UV (260-280 nm) dan Vis (490$550 \mathrm{~nm}$ ) (Syukri et al., 2013). Berdasarkan hasil analisis dari ekstrak kulit buah manggis menggunakan spektrofotometri UV-Vis, pada noda 2 ekstrak kulit buah manggis termasuk senyawa antosianin karena memiliki penyerapan karakteristik pada daerah panjang gelombang UV.

Analisis spektroskopi inframerah dilakukan untuk mengidentifikasi gugus fungsi. Setiap pita serapan pada bilangan gelombang tertentu menggambarkan adanya suatu gugus fungsi spesifik. Hasil analisa berupa signal kromatogram hubungan persentase transmitan terhadap panjang gelombang. Senyawa antosianin memiliki gugus fungsi $\mathrm{O}-\mathrm{H}$ pada bilangan gelombang $3400-3300 \mathrm{~cm}-1$, gugus fungsi $-\mathrm{CH} 3,-\mathrm{CH} 2,-\mathrm{CH}$ aldehid pada bilangan gelombang $2935-2850 \mathrm{~cm}$ 1 , gugus fungsi $\mathrm{C}=\mathrm{C}$ (aromatic dan alfatik), dan $\mathrm{C}=\mathrm{N}$ pada bilangan gelombang $1650 \mathrm{~cm}-1$, dan gugus fungsi $\mathrm{C}-\mathrm{H}$ bending pada bilangan gelombang $1420 \mathrm{~cm}-1$ (Ahmed et al., 2013). Berdasarkan hasil spektrum inframerah kulit buah manggis pada noda 2 termasuk dalam senyawa antosianin karena memiliki kemiripan gugus fungsi, sedangkan pada noda 1 tidak termasuk senyawa antosianin karena tidak memiliki gugus fungsi $C=C$ (Ahmed et al., 2013).

Kemudian dihitung penentuan kadar total senyawa antosianin dari hasil panjang gelombang dan absorban yang telah didapatkan dari supernatan yang di ambil dari noda 2 uji KLT Preparatif. Hasil penentuan kadar total antosianin $\lambda \max =367 \mathrm{~nm}$ yaitu $=9,58 \mathrm{mg} / 100 \mathrm{~g}$ dan $\lambda \max =$ $289 \mathrm{~nm}$ yaitu $=52,43 \mathrm{mg} / 100 \mathrm{~g}$.

Selanjutnya dilakukan uji stabilitas dari ekstrak kulit buah manggis yaitu uji stabilitas suhu dan uji stabilitas $\mathrm{pH}$. Sebelum itu larutan terlebih dahulu diukur absorbannya dengan memakai panjang gelombang yang sudah didapatkan yaitu $367 \mathrm{~nm}$ dan $289 \mathrm{~nm}$. Dibuat larutan induk dalam 1000 ppm, sebanyak 100 mg sampel dilarutkan dalam $100 \mathrm{~mL}$ aquadest, selanjutnya ukur absorban dengan spektrofotometer UV-Vis. Sehingga didapatkan nilai absorban dari ekstrak kulit buah manggis tanpa perlakuan yaitu 0,555 dengan panjang gelombang $367 \mathrm{~nm}$ dan 0,351 dengan panjang gelombang $289 \mathrm{~nm}$ (sebagai data untuk uji stabilitas tanpa perlakuan).

Uji stabilitas zat warna dari ekstrak kulit buah manggis terhadap suhu pemanasan dilakukan dengan cara pipet $10 \mathrm{~mL}$ dari larutan induk 1000 ppm ekstrak kulit buah manggis dimasukkan ke dalam tabung reaksi kemudian pada variasi temperatur $30^{\circ} \mathrm{C}, 50{ }^{\circ} \mathrm{C}, 70{ }^{\circ} \mathrm{C}, 90^{\circ} \mathrm{C}$ dan 100 ${ }^{\circ} \mathrm{C}$ dalam waktu 30 menit kemudian diukur absorbannya menggunakan spektrofotometer UV- 
Vis (gambar 5). Hasil uji stabilitas terhadap suhu pemanasan dengan variasi suhu menunjukan bahwa adanya peningkatan absorban pada suhu 50 OC hal ini disebabkan karena pengaruh pemanasan yang tidak stabil seharusnya semakin meningkatnya suhu pemanasan maka nilai absorban akan semakin menurun. Dengan semakin lamanya suhu pemanasan maka akan mengakibatkan pigmen warna mengalami dekomposisi dan nilai absorbannya menurun (Alvionita et al., 2016).Selanjutnya uji stabilitas pH dilakukan dengan cara pipet $10 \mathrm{~mL}$ dari larutan induk 1000 ppm ekstrak kulit buah manggis dimasukkan ke dalam tabung reaksi pada variasi $\mathrm{pH} 1,3,5,7,9$, dan 11 didiamkan selama 30 menit kemudian diukur absorbannya menggunakan spektrofotometer UV-Vis.

Pengaturan larutan ekstrak terhadap variasi $\mathrm{pH}$ dilakukan dengan cara menambahkan larutah $\mathrm{NaOH}$ atau $\mathrm{HCl}$ terhadap variasi $\mathrm{pH}$ yang diinginkan. Hasil uji stabilitas terhadap $\mathrm{pH}$ menunjukan bahwa ekstrak kulit buah manggis nilai absorban tinggi pada $\mathrm{pH} 5$ dan rendah pada pH 1,3,7 dan 9 (gambar 6). Ini menunjukan bahwa adanya pengaruh penambahan $\mathrm{HCl}$ dan $\mathrm{NaOH}$ pada stabilitas senyawa antosianin. Semakin tinggi pH maka warna dari pigmen antosianin akan berubah menjadi senyawa kalkon yang tidak berwarna.

Kemudian Apilkasi zat warna alami pada pembuatan tablet parasetamol bertujuan untuk apakah zat pewarna tersebut dapat digunakan sebagai zat pewarna alami atau tidak. Hasil pengamatan diperoleh warna coklat kemerahan (gambar 7) ini menunjukan adanya kandungan senyawa antosianin di dalam ekstrak kulit buah manggis, tapi setelah diaplikasikan ke dalam sediaan tablet, warna yang dihasilkan kurang menarik dan tidak stabil berubah menjadi warna coklat kekuningan ini disebabkan karena pewarna alami sangat mudah teroksidasi akibat pengaruh cahaya, pemanasan dan perubahan $\mathrm{pH}$ sehingga intensitas warnanya berkurang. Dari analisa tersebut dapat disimpulkan pigmen antosianin didalam ekstrak kulit buah manggis tidak dapat menjadi alternatif penggunaan pewarna alami untuk sediaan farmasi (tablet).

\section{KESIMPULAN}

Profil fisikokimia ekstrak kulit buah manggis sebagai pewarna alami dilakukan dengan dua metode yaitu pemeriksaan dengan spektrofotometri UV-Vis dan FTIR. Hasil uji spektrofotometri UV-Vis ekstrak kulit buah manggis pada noda 1 memiliki nilai $\lambda \max =367$ $\mathrm{nm}$ dengan nilai absorban $=0,188$ dan $\lambda \max =$ $296 \mathrm{~nm}$ dengan nilai absorban $=0,551$, sedangkan pada noda 2 memiliki nilai $\lambda \max =367$ $\mathrm{nm}$ dengan nilai absorban $=0,287$ dan $\lambda$ max $=$ $289 \mathrm{~nm}$ dengan nilai absorban $=1,570$. Ekstrak diaplikasikan dalam pembuatan tablet paracetamol, Namun warna yang dihasilkan kurang menarik dan warna tidak stabil pada suhu dan $\mathrm{pH}$ tertentu serta mudah terdegradasi, sehingga dapat disimpulkan pigmen antosianin didalam ekstrak kulit buah manggis tidak dapat menjadi alternatif penggunaan pewarna alami untuk sediaan farmasi (tablet).

\section{REFERENSI}

Ahmed, J.K., Salih, H. A.M., Angham, \& Hadi, G. (2013). Anthocyanin in Red Beet Juice Act as Seavengers for Heavy Metals lons such as Lead and Cadmium. International Journal of Science and Tecnology, 2,(3), 269-274.

Almeyda, N. dan Martin, F. W., 1976, Cultivation of neglected tropical fruits with promise I, The Mangosteen (Garcinia mangostana L.), Us Agricultural Research Service South Region 155:1-18.

Alvionita, J. Darwis , D. \& Efdi, M. (2016). Ekstraksi dan Identifikasi Senyawa Antosianin dari Jantung Pisang Raja ( Musa X Paradisica L.) Serta Uji Kativitas Antioksidannya. J. Ris. Kim. Vol. 9, No.2.

Banker,G.S, dan Anderson N.R. (1994). Tablet. Dalam: Teori Dan Praktek Farmasi Industri. Edisi III, Jilid II. Editor: Lachman. L penerjemah: Siti Suryatmi, Jakarta:UlPress. Hal.643-703.

Charley, H., (1970), Food Science, John Willey and Sons Inc, New York

Chemat, F., Zill, H., \& Muhammad, K. 2011. Applications of Ultrasound In Food Technology: Processing, Preservation and Extraction. Journal Ultrasonic Sonochemistry, Volume 18.813-835.

Dachriyanus, D. (2004). Analisis Spektrum Senyawa Organik Secara Spektroskopi. Padang : Penerbit Universitas Andalas.

Demann, J. M. (1997). Kimia Makanan (Edisi 2). Penerjemah: Padmawinata K. Bandung: Penerbit ITB. 
Departemen Kesehatan Republik Indonesia. (2000). Parameter Standar Umum Ekstrak Tumbuhan Obat. Jakarta: Direktorat Jenderal Pengawasan Obat dan Makanan, Direktorat Pengawasan Obat Tradisional.

Departemen Kesehatan Republik Indonesia. (2008). Farmakope herbal Indonesia (Edisi I). Jakarta: Departemen Kesehatan Republik Indonesia.

Fennema, \& Owen R. (1996). Food chemistry (3rd ed). New York : Marcel Dekker. Inc.

Frank M. \& White. (1986). Mekanika fluida. (Jilid I). Jakarta : Penerbit Erlangga.

Gandjar, I. G. \& Rohman, A. (2012). Analisis obat secara spektrofotometri dan kromatografi. Yogyakarta: Pustaka Pelajar.

Harborne, J. B. 1987. Metode Fitokimia Penuntun Cara Modern Menganalisis Tumbuhan, Terbitan kedua. Bandung: ITB.

Heldman, D. R., \& P.R. Singh. (1981). Food proses engineering. $\left(2^{\text {nd }} \mathrm{ed}\right)$. The AVI Publ. Westport : Comp. Inc.

Heyne, K (1987). Tumbuhan Berguna Indonesia. Jilid III. Cetakan-1. Yayasan Saran Wana Jaya. Jakarta. Hal 1534.

Hidayat, N., \& Saati, E. A. (2006). Membuat pewarna alami. Surabaya: Penerbit trubus Agrisarana.

Hutapea, J.R. 1994. Inventaris Tanaman Obat Indonesia jilid III. Badan Penelitian dan Pengembangan Kesehatan. Jakarta. 332 hlm.

Kementerian Kesehatan Republik Indonesia. (2011). Suplemen II Farmakope Herbal Indonesia Edisi I. Jakarta: Departemen Kesehatan Republik Indonesia.

Kementerian Kesehatan Republik Indonesia. (2014). Farmakope Indonesia Edisi V. Jakarta: Kementerian Kesehatan Republik Indonesia.

Lestario, L.N., Raharjo, S., Suparmo, Hastuti, P. dan Tranggono (2004). Fractination and identification of Java plum (Syzygium cumini) fruit extract. Journal Indonesian Food and Nutrition Progress 11: 41-47.

Liapis, A. I. \& Bruttini, R. (1995). Freeze drying.(Eds). Handbook of Industrial Drying. (p.309-343). New York : Marcel Dekker. Inc.

Marjoni, M.R.(2016). Dasar- dasar fitokimia. Jakarta: CV. Trans Info Media.
Markham, K. R. (1988). Cara Mengidentifikasi Flavonoid. Penerjemah : Kosasih Padmawinata. Bandung : Penerbit ITB.

Mason TJ. 1990. Sonochemistry: The Use of Ultrasonic in Chemistry. Volume ke 1. Chambridge (UK): Royal Society of Chemistry.

McClements, D. J. (1995). Advances in the application of ultrasound in food analysis and processing. Trends Food Science Technology, 6(2), 293-299.

Nugraheni, M. (2014). Pewarna Alami : Sumber Daya dan Aplikasinya pada Makanan dan Kesehatan. Yogyakarta : Graha IImu.

Permana, A. (2010). Kulit Buah Manggis dapat menjadi Minuman Instan Kaya Antioksidan. Warta Penelitian dan Pengembangan Pertanian 2010; 32(2): 5-7.

Prihatman, K., 2000, Manggis (Garcinia mangostana L.), Kantor Deputi Menegristek Bidang Pendayagunaan dan Pemasyarakatan IImu Pengetahuan dan Teknologi BPP Teknologi, Jakarta.

Purwakusumah, E. D., Mohamad, R., Utami D. S., Waras N., \& Muhammad A. Z.A. (2014). Identification and authentication of Jahe merah using combination of FTIR spectrocopy and chemometrics. Journal AGRITECH. 34(1), 82-87.

Ramli, N.S., Ismail, P., \& Rahmat,A. 2014. Influence of Conventional and UltrasonicAssisted Extraction on Phenolic Contents, Betacyanin Contents, and Antioxidant Capacity of Red Dragon Fruit (Hylocereuspolyrhizus). The Scientific World Journal, Volume 2014 (1). 1-7.

Rauf, R. (2015). Kimia pangan. Yogyakarta : Penerbit ANDI.

Rukmana, R., (1995). Budidaya Manggis, Kasinus, Yogyakarta.

Sholihah, M., Ahmad, U., \& Budiastra, W., (2017). Aplikasi Gelombang Ultrasonik untuk Meningkatkan Rendemen Ekstraksi dan Efektifitas Antioksi pada Kulit Manggis. Jurnal keteknikan pertanian, vo.5. no.2,p 161-168.

Syukri, D., Darwis, D., \& Santoni, A. (2013). Simple Characterization of Anthocyanins from Ficus PandanUS Burm. F., Journal of Chemical and Pharmaceutical Research, 5, 9120,1276-1282 
Sulekova, M., Smrcova, M., Hudak, A., Hezelova, M., \& Fedorova, M. (2017). Organic colouring agents in the pharmaceutical industry. Folia Veterinaria, 61 ( 3), 32-46.

Tahid. (2004). Spektrofotometri UV-Vis: prinsip dasar, peralatan dan pemeliharaannya. Bandung: Pusat Penelitian Kimia Lembaga IImu Pengetahuan Indonesia.

Watson, D. G. (2005). Analisis farmasi. (Edisi 2). Penerjemah: W.R. Syarief. Jakarta: Penerbit Buku Kedokteran.

Widyasanti, A., Nurlaily, N., \& Wulandari, E. (2018). Karakteristik Fisikokimia Antosianin Ekstrak Kulit Buah Naga Merah Menggunakan Metode UAE. Jurnal IImiah Rekayasa Pertanian dan Biosistem, Vol. 6, No1.

Winarno, F.G . (1997). Kimia Pangan dan Gizi. Jakarta: Gramedia Pustaka Utama. 